\title{
In vitro antioxidant and antibacterial activity of endophytic fungi isolated from Mussaenda luteola
}

\author{
Shylaja Gunasekaran, Mythili Sathiavelu, Sathiavelu Arunachalam* \\ School of Biosciences and Technology, VIT University, Vellore-632014, Tamilnadu, India.
}

\begin{tabular}{|c|c|}
\hline ARTICLE INFO & ABSTRACT \\
\hline $\begin{array}{l}\text { Article history: } \\
\text { Received on: } 10 / 05 / 2017 \\
\text { Accepted on: } 10 / 06 / 2017 \\
\text { Available online: } 30 / 08 / 2017\end{array}$ & $\begin{array}{l}\text { Diverse group of endophytic fungi exist within every plant tissues which constitute major and novel natural } \\
\text { therapeutic compounds. Hence we investigated five fungal endophytes associated with the medicinal plant } \\
\text { Mussaenda luteola L. (Rubiaceae) for the presence of phytochemicals, total phenolic, total flavonoid content, } \\
\text { antioxidant and antibacterial activity. The results revealed that the ethyl acetate extract of Alternaria sp. (ML4) }\end{array}$ \\
\hline $\begin{array}{l}\text { Key words: } \\
\text { Mussaenda luteola, } \\
\text { Endophytic fungi, } \\
\text { Phytochemicals, Antioxidant } \\
\text { activity, Antibacterial } \\
\text { activity. }\end{array}$ & $\begin{array}{l}\text { of extract respectively. It also had DPPH scavenging activity of } 85.20 \% \text { at the concentration of } 300 \mu \mathrm{g} / \mathrm{ml} \text { and } \\
\text { high reducing power activity. The remaining fungal extracts exhibited significant level of total phenolic and } \\
\text { flavonoid content, antioxidant and antibacterial activity. This study shows that the endophytic fungi isolated } \\
\text { from } M \text {. luteola can be a potential antioxidant and antibacterial resource. }\end{array}$ \\
\hline
\end{tabular}

\section{INTRODUCTION}

Endophytic fungi reside within most tissues of the living plants which are known to possess different rare and novel secondary metabolites (Ibrahim et al., 2015). It proved to be one of the most important and diverse resources available for active natural products with significant biological activities (Peng et al., 2013). There are large number of bioactive compounds that have been isolated and identified from endophytic fungi which has various biological activities such as antioxidant, anticancer, antiviral, immunomodulatory, antitubercular, insecticidal and antiparasitic activities. So these bioactive natural products have a wide application in pharmaceuticals and agrochemical industries (Hussain et al., 2014; Chomcheon et al., 2009). Free radicals are reactive oxygen species often generated by various biological reactions in our body or from exogenous factors. These free radicals cause oxidative stress leading to damage membrane

\footnotetext{
* Corresponding Author

Sathiavelu Arunachalam, Associate professor, SBST, VIT University, Vellore-632014, India. E mail: asathiavelu@vit.ac.in
}

lipids, proteins, enzymes and DNA. It is responsible for many degenerative human diseases like diabetes mellitus, Alzheimer's, Parkinson's disease, ageing, atherosclerosis and inflammatory diseases etc. (Jayanthi et al., 2011; Yadav et al., 2014). Apart from dietary intake, sufficient amounts of exogenous antioxidants would prevent the pathological conditions induced by free radicals (Bharathidasan et al., 2012). There are many antioxidant compounds, for example pestacin and isopestacin, have been obtained from the culture of Pestalotiopsis microspora, an endophytic fungi isolated from the medicinal plant Terminalia morobensis (Strobel and Daisy, 2003). These endophytic microorganisms can also be used as antimicrobial agents since it produces wide structural classes of secondary metabolites such as alkaloids, peptides, steroids, terpenoids, phenols, quinones and flavonoids. The development of new antibiotics is important to overcome the increasing threat of drug resistant human pathogenic strains (Garcia et al., 2012; Sahu et al., 2014). The genus Mussaenda belongs to Rubiaceae family which is native to West Africa through the Indian sub-continent, South East Asia and Southern China. 
Some important species were widely distributed in Central Nepal, India and Srilanka. It has been reported to possess many medicinal properties. Their medicinal activities include cytotoxicity, anti-inflammatory, antiviral, antioxidant and antibacterial properties (Vidyalakshmi et al., 2008). Hence we investigated the total phenolic content, total flavonoid content, antioxidant capacities and antibacterial activity of endophytic fungi isolated from the medicinal plant M. luteola.

\section{MATERIALS AND METHODS}

\section{Sample collection}

Fresh leaf, stem and root samples of M. luteola were collected from Vellore district, Tamilnadu in the month of June 2016. The collected samples were placed in sterile plastic bags and brought to the laboratory on the same day.

\section{Isolation of endophytic fungi}

The samples were surface sterilized according to the method described by Schulz et al. 1993. The small segments of surface sterilized samples were placed on Potato Dextrose Agar (PDA) medium supplemented with $150 \mathrm{mg} / \mathrm{L}$ streptomycin to prevent bacterial growth. Plates were incubated at $26^{\circ}-30^{\circ} \mathrm{C}$ for a week (Dhankhar et al., 2012). The emerging endophytic fungi were isolated, purified and maintained by continuous subculturing (Jayanthi et al., 2011).

\section{Identification of endophytic fungi:}

Isolated fungi were identified on the basis of their colony or hyphal morphology, pigmentation, aerial mycelium, surface texture and characteristics of the spores using various standard manuals. Also microscopic studies were done by lactophenol cotton blue staining (Sadananda et al., 2014).

\section{Extraction of crude secondary metabolic compounds}

The fungal endophytes were cultivated on $500 \mathrm{ml}$ Potato Dextrose Broth (Himedia) and were incubated as static culture at $26 \pm 2{ }^{\circ} \mathrm{C}$ for 1 Week. After the incubation period, mycelium was separated from the fermented liquid broth by filtration and the filtrate was extracted by solvent extraction using ethyl acetate. All the solvent was evaporated and the resultant compound was dried and the crude extract was obtained (Madki et al., 2010; Sadananda et al., 2011).

\section{Preliminary phytochemical screening of fungal extract}

The crude ethyl acetate extract was used for phytochemical screening to analyse the presence of various secondary metabolites such as alkaloids, phenols, flavonoids, steroids, terpenoids, saponins, tannins (Bhardwaj et al., 2015).

\section{Determination of total phenolic content}

Total phenol content of ethyl acetate extract obtained from five different endophytic fungi was estimated using FolinCiocalteau reagent based assay using gallic acid as standard. Each extract $(1 \mathrm{mg} / \mathrm{mL})$ of $100 \mu \mathrm{l}$ was added with $500 \mu \mathrm{L}$ of $1 \mathrm{~N}$ Folin -
Ciocalteau reagent. Then $1.5 \mathrm{~mL}$ of $20 \%$ of $\mathrm{NaCO}_{3}$ was added to the mixture. Final volume was made $5 \mathrm{~mL}$ by adding distilled water. The mixture was incubated for $30 \mathrm{~min}$ at room temperature and the absorbance of the developed colour was recorded at 765 $\mathrm{nm}$ using UV-vis spectrophotometer. The same procedure was done with $1 \mathrm{~mL}$ aliquot of 5,10 to $50 \mu \mathrm{g} / \mathrm{mL}$ gallic acid were used as standard for calibration curve (Jayanthi et al., 2011).

\section{Determination of total flavonoid content:}

Total flavonoid content of ethyl acetate extract obtained from five different endophytic fungi was estimated using Aluminium chloride colorimetric method (Saravanan and Parimelazhagan, 2014). The extract $(1 \mathrm{mg} / \mathrm{mL})$ of $100 \mu \mathrm{l}$ was mixed with $2 \mathrm{~mL}$ of distilled water and $0.15 \mathrm{~mL}$ of $5 \% \mathrm{NaNO}_{2}$ solution. Then after $6 \mathrm{~min}, 0.15 \mathrm{~mL}$ of $10 \% \mathrm{AlCl}_{3}$ of was added and the mixture was allowed to stand for another $6 \mathrm{~min}$, then $2 \mathrm{~mL}$ of $4 \% \mathrm{NaOH}$ solution was added.

The final volume was made up to $5 \mathrm{~mL}$ by adding distilled water immediately and the mixture was allowed to stand for $15 \mathrm{~min}$ at room temperature. Absorbance was recorded at 510 nm using UV-vis spectrophotometer. Rutin was used as a standard compound for quantification of flavonoid and the results were expressed as rutin equivalents (RE).

\section{Antioxidant assays}

DPPH (2, 2-diphenyl-1-picrylhydrazyl) Assay:

For DPPH assay (Asker et al., 2013), aliquots of extract at different concentration were added to $2 \mathrm{ml}$ of (DPPH) methanolic solution $(0.1 \mathrm{mM})$. The reaction mixture was shaken well and incubated at room temperature for $10 \mathrm{mins}$. The absorbance of the resulting solution was read at $517 \mathrm{~nm}$ against a blank. The radical scavenging activity was calculated using the following equation:

Scavenging ability $(\%)=[(\Delta \mathrm{A} 517$ of control $-\Delta \mathrm{A} 517$ of sample $) /$ $\triangle \mathrm{A} 517$ of control] $\times 100$

\section{Reducing power assay}

The reducing power assay was performed for each sample extract $(1 \mathrm{mg} / \mathrm{mL})$ at different concentrations and first mixed with $2.5 \mathrm{~mL} 0.2 \mathrm{M}$ phosphate buffer, $\mathrm{pH} 6.6$ and $2.5 \mathrm{~mL} 1 \%$ potassium ferricyanide. After incubation for $20 \mathrm{~min}$ at $50^{\circ} \mathrm{C}, 2.5$ $\mathrm{mL} 10 \%$ trichloro acetic acid was added to the mixture and then centrifugation was done at $3000 \mathrm{rpm}$ for $10 \mathrm{~min}$. Subsequently, 2.5 $\mathrm{mL}$ of the supernatant was added to $2.5 \mathrm{~mL}$ distilled water and 0.5 $\mathrm{mL} 0.1 \%$ ferric chloride, and the absorbance of the resulting solution was read at $700 \mathrm{~nm}$ against a blank. Ascorbic acid was used as positive controls (Zeng et al., 2011).

\section{Antibacterial assay}

The antibacterial assay was carried out by agar well diffusion technique. The Mueller Hinton Agar plates were swabbed with $0.1 \mathrm{ml}$ culture of different bacterial clinical isolates obtained from microbiology department VIT University, Vellore 
(Escherichia coli, Bacillus subtilis, Staphylococcus aureus and Pseudomonas aeruginosa). The respective wells were poured with each sample extract of $30 \mu \mathrm{L} /$ well $(1 \mathrm{mg} / \mathrm{ml}$ concentration). In other wells, DMSO was used as a negative control and standard antibiotic chloramphenicol was used as positive control. The experiment was carried out in triplicate. The plates were incubated at $37^{\circ} \mathrm{C}$ for 24 hours and results were recorded as zone of inhibition in $\mathrm{mm}$. (Desale et al., 2013).

\section{Statistical analysis}

All results are reported as means \pm standard deviation. The statistical analysis was done using one way ANOVA. The ' $\mathrm{P}$ value' found to be $<0.05$, was considered as significant.

\section{RESULTS AND DISCUSSION}

\section{Isolation and identification of endophytic fungi}

The healthy leaf, stem and root of the plant M. luteola were subjected to isolate the endophytic fungi and the identification was based on colony morphology and microscopic studies. The colony morphology and frequency of occurrence of each endophytic fungus was noticed. The results are presented in Table 1.

Table 1: Frequency of occurrence and colony morphology of endophytic fungi in different parts of the plant

\begin{tabular}{ccccc}
\hline \multirow{2}{*}{ Endophytic fungi } & Colony morphology & \multicolumn{3}{c}{$\begin{array}{c}\text { Frequency of } \\
\text { occurrence }\end{array}$} \\
\cline { 3 - 5 } & & Leaves & Stem & Root \\
\hline $\begin{array}{c}\text { Aspergillus } s p . \\
\text { (ML1) }\end{array}$ & $\begin{array}{c}\text { Carbon black mycelia, } \\
\text { brownish on reverse }\end{array}$ & 3 & - & - \\
\hline $\begin{array}{c}\text { White cottony } \\
\text { Xylaria } s p . \text { (ML2) }\end{array}$ & $\begin{array}{l}\text { mycelium, golden } \\
\text { blonde on reverse }\end{array}$ & 2 & - & - \\
\hline $\begin{array}{c}\text { Penicillim } s p . \\
\text { (ML3) }\end{array}$ & $\begin{array}{c}\text { White to pale brown } \\
\text { mycelium, reddish } \\
\text { brown on reverse }\end{array}$ & 1 & 1 & - \\
\hline $\begin{array}{c}\text { Alternaria } s p . \\
\text { (ML4) }\end{array}$ & $\begin{array}{c}\text { Pale grayish hyphae, } \\
\text { black on reverse }\end{array}$ & 2 & 1 & - \\
\hline $\begin{array}{c}\text { Unknown } s p . \\
\text { (ML5) }\end{array}$ & $\begin{array}{c}\text { White mycelium, pale } \\
\text { yellow on reverse }\end{array}$ & 2 & 2 & - \\
\hline
\end{tabular}

\section{Phytochemical screening}

The ethyl acetate extract of all endophytic fungus were subjected to phytochemical analysis to check for the presence of phenols, alkaloids, flavonoids, steroids, saponins, terpenoids, tannins and the results are presented in Table 2. These chemical constituents are responsible for different medicinal properties of extracts. The yield of ethyl acetate extract of all fungus was found to be $1.0-1.8 \mathrm{~g} / 500 \mathrm{ml}$

Table 2: Phytochemicals present in ethyl acetate extract of endophytic fungi

\begin{tabular}{cccccc}
\hline Phytochemical & $\begin{array}{c}\text { Aspergillus } \\
\text { sp. }(\text { ML1 })\end{array}$ & $\begin{array}{c}\text { Xylaria } \\
\text { sp. } \\
(\text { ML2) }\end{array}$ & $\begin{array}{c}\text { Penicillium } \\
\text { sp. }(\text { ML3) }\end{array}$ & $\begin{array}{c}\text { Alternaria } \\
\text { sp. }(\text { ML4) }\end{array}$ & $\begin{array}{c}\text { Unkno } \\
\text { wn sp. } \\
(\text { ML5) }\end{array}$ \\
\hline Phenol & + & + & - & + & - \\
Flavaonoid & + & - & + & + & - \\
Alkaloid & - & - & - & - & - \\
Terpenoid & - & - & - & - & - \\
Steroid & - & - & - & - & - \\
Saponin & + & + & - & + & + \\
Tannin & + & - & - & + & - \\
\hline
\end{tabular}

Note: + means Presence; - means not present.

\section{Determination of Total phenolic and flavonoid content}

There was a wide range of total phenolic and flavonoid concentrations were found in different endophytic fungal extracts. The highest concentration of phenol $(108.65 \pm 0.12 \mathrm{mg}$ of GAE/g of extract) and flavonoid (56.45 \pm 0.10$)$ was observed in ethyl acetate extract of ML4. The results were presented in Table 3.

Table 3: Total phenolic and flavonoid content of ethyl acetate extract from endophytic fungus

\begin{tabular}{ccc}
\hline Endophytic fungi & $\begin{array}{c}\text { Total phenolic content } \\
\text { (mg of GAE/g of } \\
\text { extract) }\end{array}$ & $\begin{array}{c}\text { Total flavonoid } \\
\text { content (mg of } \\
\text { RE/g of extract) }\end{array}$ \\
\hline Alternaria Sp (MLL1) & $32.77 \pm 0.04^{\mathrm{b}}$ & $18.62 \pm 0.02^{\mathrm{b}}$ \\
Xylaria Sp (MLL2) & $28.15 \pm 0.02^{\mathrm{c}}$ & $15.85 \pm 0.08^{\mathrm{c}}$ \\
Penicillim Sp (MLL4) & $24.38 \pm 0.03^{\mathrm{d}}$ & $15.62 \pm 0.05^{\mathrm{d}}$ \\
Penicillim Sp (MLL6) & $108.65 \pm 0.12^{\mathrm{a}}$ & $56.45 \pm 0.10^{\mathrm{a}}$ \\
Unknown (MLS1) & $9.59 \pm 0.04^{\mathrm{e}}$ & $5.01 \pm 0.03^{\mathrm{e}}$ \\
\hline
\end{tabular}

Note: Values are expressed as mean \pm standard deviation $(n=3)$. Mean values followed by different superscript letters indicate significant statistical difference $(\mathrm{P}<0.05)$

\section{Antioxidant assay}

In present study, ethyl acetate extract of five different endophytic fungi were investigated for antioxidant potential by using two different assays. All extract of five different endophytic fungi showed antioxidant activity up to varying extent.

\section{DPPH radical scavenging activity}

DPPH, a stable free radical was used to study the radical scavenging effects of the fungal extract. As antioxidant donate proton to this radical, this decreases the absorption. The reaction was visible as a colour change from purple to yellow. The EA extract of Alternaria sp. (ML4) showed a high scavenging activity of $85.20 \%$ whereas the Unknown sp. (ML5) showed the least antioxidant activity of $33.95 \%$. Ascorbic acid was taken as standard showing $96.91 \%$ antioxidant activity. Percentage of DPPH radical scavenging activity of endophytic fungi and ascorbic acid is shown in Figure 2

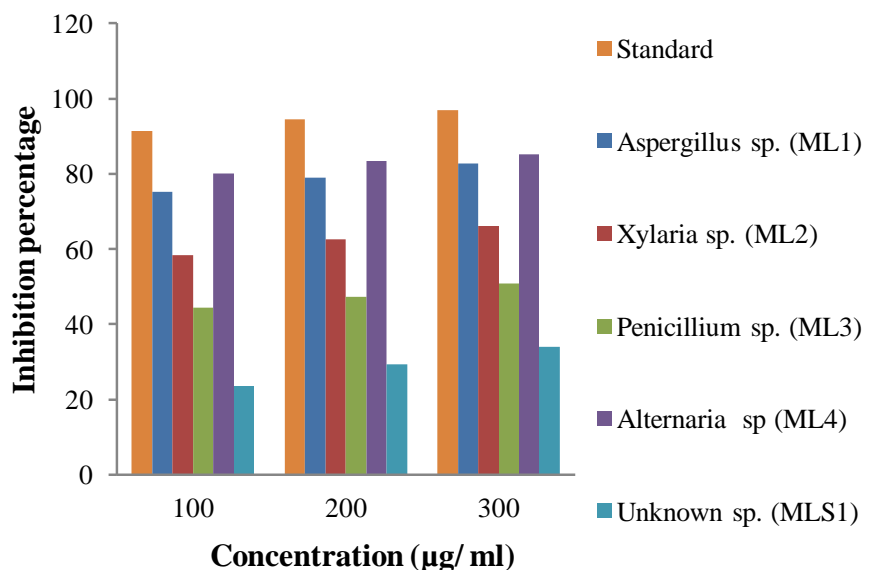

Fig. 2: DPPH free radical scavenging activity of ethyl acetate of all endophytic fungus.

Reducing power assay

In reducing power assay reducing ability was measured by reaction change of $\mathrm{Fe} 3+$ to $\mathrm{Fe} 2+$. The EA extract of ML4 had 
high absorbance values more than standard that indicated higher reductive potential and electron donor ability for stabilizing free radicals. Reducing power of all endophytic fungal extract and ascorbic acid with respect to their absorbance values are shown in Figure 3.

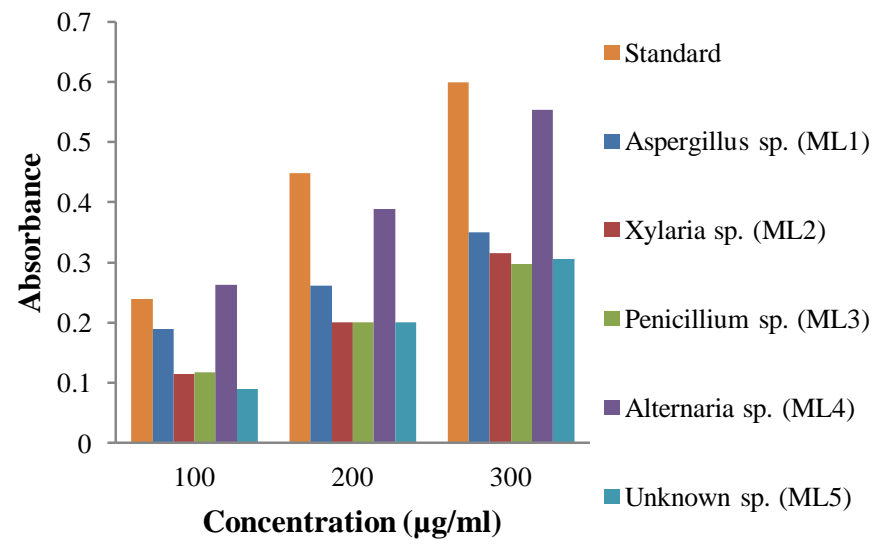

Fig. 3: Reducing power activity of ethyl acetate extract from all endophytic fungus.

\section{Antibacterial activity}

The crude extract obtained from five endophytic fungi was subjected for its anti-microbial activity against two gram positive bacteria (B. subtilis, $S$. aureus) and two gram negative bacteria ( $E$. coli, $P$. aeruginosa). The results revealed that the Alternaria sp. (ML4) showed more antibacterial activity against all organisms and Aspergillus sp. (ML1), Penicillium sp. (ML3) shows significant activity against E.coli and P.aeroginosa. The standard antibiotic chloramphenicol was used as a positive control. The diameter of zone of inhibition was measured in millimeters and presented in Table 4.

Table 4: Antimicrobial activity of endophytic fungus on Test organisms (determined by diameter of inhibition zones).

\begin{tabular}{lllll}
\hline \multirow{2}{*}{ Endophytic fungus } & \multicolumn{5}{c}{ Zone of inhibition (mm) } \\
\cline { 2 - 5 } & \multicolumn{1}{c}{$\begin{array}{c}\boldsymbol{P} \text {. } \\
\text { coli }\end{array}$} & $\begin{array}{c}\text { aeruginosa } \\
\text { subtilis }\end{array}$ & $\begin{array}{c}\text { S. } \\
\text { aureus }\end{array}$ \\
\hline Aspergillus sp. (ML1) & 10 & 9.2 & - & 9.0 \\
Xylaria sp. (ML2) & - & - & 5.6 & - \\
Penicillium sp. (ML3) & 8.9 & 8.6 & - & - \\
Alternaria sp. (ML4) & 11.5 & 10.0 & 9.3 & 10.7 \\
Unknown sp. (ML5) & - & - & - & - \\
Chloramphenicol & 14 & 15 & 14 & 13 \\
\hline
\end{tabular}

\section{DISCUSSION}

Medicinal plants provide a special environment for endophytic organisms. Many previous studies reported endophytic fungi isolated from medicinal plant have novel and bioactive natural products. These fungi have been isolated from the leaf, stem or inner bark tissues of the plant (Gurupavithra and Jayachitra, 2013). Medicinal plants usually harbour endophytes with similar secondary metabolites and pharmacological activities as host plant (Yadav et al., 2014). The genus Mussaenda is an important source of pharmacologically active natural products, particularly iridoids, triterpenes and flavonoids (Vidyalakshmi et al., 2008). In this study, endophytic fungi were isolated from $M$. luteola was investigated for the presence of various phytochemicals, total phenolic content, antioxidant and antibacterial activity.

Ethyl acetate extraction is most efficient method of isolating secondary metabolites from fungal species (Yadav et al., 2014), so all assays were carried out in ethyl acetate extract. The phytochemical analysis confirms the presence of phenols, flavonoids, alkaloids, terpenoids and saponins to varying concentration. Phenolic and flavonoid compounds seem to have an important role in reducing lipid peroxidation and hence act as primary and secondary antioxidants (Pawle et al., 2014).

Among different antioxidant assays, DPPH free radical scavenging assay is the most widely used assay and it is considered to be the most accurate screening method used to evaluate the antioxidant activity. Also DPPH is not affected by metals or enzyme inhibition (Yadav et al., 2014).

In reducing power assay, the compound exhibit antioxidant activity by breaking the free radical chain through donation of a hydrogen atom (Ravindran et al., 2012).

The increase in radical scavenging ability may have been due to increase in the concentration of total phenol compounds (Govindappa et al., 2013). In this study, all fungal extract had a wide range of scavenging ability. Among that, ethyl acetate extract of Alternaria sp. (ML4) showed $85.20 \%$ inhibition activity against DPPH which is nearly equivalent to ascorbic acid with the inhibition activity of $96.91 \%$, also it shows high reducing power activity compared to standard ascorbic acid with the highest total phenolic and flavonoid concentration of $108.65 \pm 0.12 \mathrm{mg}$ of $\mathrm{GAE} / \mathrm{g}$ and $56.45 \pm 0.10 \mathrm{mg}$ of $\mathrm{RE} / \mathrm{g}$ of extract respectively. Remaining fungal extracts showed significant level of antioxidant activity. A good correlation was found between the level of total phenol, flavonoid contents and antioxidant ability for all the extracts. The fungal extract with high scavenging and reducing power activity had a significant amount of total phenol concentration. In antibacterial assay, Alternaria sp. (ML4) showed high activity against both gram positive and gram negative bacteria. Aspergillus sp. (ML1) and Penicillium sp. (ML3) showed significant activity against $E$. coli, $P$. aeroginosa. The different sensitivity between Gram positive and Gram negative bacteria could be due to cell wall morphological differences between these microorganisms. (Sadrati et al., 2013). Our study demonstrated that the endophytic fungus isolated from M. luteola plant had significant range of biological activities and presence of phytochemicals which on further purification the active compounds can be obtained.

\section{CONCLUSION}

The present study concludes that the endophytic fungal extract exhibited antioxidant and antimicrobial activity due to the presence of bioactive natural compounds. Furthermore, active crude extracts are being subjected to purification process for identification of active compounds which may provide a better 
source for developing new pharmacological agents. These active natural compounds have a potential application as antioxidants and antibacterial agents in many pharmaceutical products.

\section{ACKNOWLEDGEMENTS}

The authors thank the VIT University for providing the opportunity to carry out the research.

\section{Financial support and sponsorship: Nil.}

Conflict of Interests: There are no conflicts of interest.

\section{REFERENCE}

Asker MMS, Mohamed SF, Mahmoud MG, El Sayed OH. Antioxidant and antitumor activity of a new sesquiterpene isolated from endophytic fungus Aspergillus glaucus. Int J PharmTech Res, 2013; 5(2): 391-397.

Bharathidasan R, Panneerselvam A. Antioxidant activity of the endophytic fungi isolated from mangrove environment of karankadu, Ramanathapuram district. Int J Pharm Sci Res, 2012; 3(8): 2866-2869.

Bhardwaj A, Sharma D, Jadon N, Agrawal PK. Antimicrobial and phytochemical screening of endophytic fungi isolated from spikes of Pinus Roxburghii. Arch Clinical Microbiol, 2015; 6(1): 1-9.

Chomcheon P, Wiyakrutta S, Sriubolmas N, Ngamrojanavanich N, Kengtong S, Mahidol C , Ruchirawat S , Kittakoop P. Aromatase inhibitory, radical scavenging, and antioxidant activities of depsidones and diaryl ethers from the endophytic fungus Corynespora cassiicola L36. Phytochem, 2009; 70: 407-413.

Desale MG, Bodhankar MG, Antimicrobial activity of endophytic fungi isolated from Vitex negundo Linn. IntJ Curr Microbiol App Sci, 2013; 2(12): 389-395.

Dhankhar S, Kumar S, Dhankhar S, Yadav JP. Antioxidant activity of fungal endophytes isolated from Salvadora oleoides decne. Int J Pharm Pharm Sci, 2012; 4(2): 380-385.

Garcia A, Rhoden SA, Bernardi-Wenzel J, Orlandelli RC, Azevedo JL, Pamphile JA. Antimicrobial activity of crude extracts of endophytic fungi isolated from medicinal plant Sapindus saponaria L. J Appl Pharm Sci, 2012; 2 (10): 035-040.

Govindappa M, Channabasava R, SunilKumar KR and Pushpalatha KC. Antioxidant activity and phytochemical screening of crude endophytes extracts of Tabebuia argentea Bur. \& K. Sch. Am J Plant Sci, 2013; 4: 1641-1652.

Gurupavithra S and Jayachitra A, Isolation and identification of endophytic fungi from Ocimum sanctum and analyse its antioxidant properties. Int J Res Pharm Biomed Sci, 2013; 4 (4): 1120-1125.

Hussain H, Kliche-Spory C, Al-Harrasi A, Al-Rawahi A, Abbas G, Green IR, Schulz B, Krohn K, Shah A. Antimicrobial constituents from three endophytic fungi. Asian Pac J Trop Med, 2014; 7(1): S224-S227.

Ibrahim SRM, Elkhayat ES, Mohamed GA, Khedr AIM, Fouade MA, Kotb MHR, Ross SA. Aspernolides F and G, new butyrolactones from the endophytic fungus Aspergillus terreus. Phytochem Lett, 2015; 14: 84-90.

Jayanthi G, Kamalraj S, Karthikeyan K, Muthumary J. Antimicrobial and antioxidant activity of the endophytic fungus Phomopsis sp. GJJM07 isolated from Mesua ferrea. Int J Curr Sci, 2011; 1: $85-90$.

Kandasamy S, Kandasamy K. Antioxident activity of the mangrove endophytic fungus (Trichoderma $s p$.). J Coastal Life Med, 2014; 2(7): 566-570.
Madki MA, Manzoor AS, Powar PV and Patil KS. Isolation and biological activity of endophytic fungi from Withania Somnifera. Int J Ph Sci, 2010; 2(3): 848-858.

Pawle G and Singh SK. Antioxidant potential of endophytic fungus Colletotrichum species isolated from Polygala elongate. Int.J.Pharm.Bio Sci, 2014; 5(3): 313 -319.

Peng W, You F, Li XL, Jia M, Zheng CJ, Han T , Qin LP. A new diphenyl ether from the endophytic fungus Verticillium sp. isolated from Rehmannia glutinosa. Chinese J Nat Med, 2013; 11: 0673-0675.

Ravindran C, Naveenan T, Varatharajan GR, Rajasabapathy R, Meena RM. Antioxidants in mangrove plants and endophytic fungal associations. Bot, 2012; 55: 269-279.

Sadananda TS, Govindappa M Ramachandra YL. In vitro Antioxidant Activity of lectin from different endophytic fungi of Viscum album L. Brit J Pharm Res, 2014; 4(5): 626-643.

Sadananda TS, Nirupama R, Chaithra K, Govindappa M, Chandrappa CP, Vinay Raghavendra B. Antimicrobial and antioxidant activities of endophytes from Tabebuia argentea and identification of anticancer agent (lapachol). J Med Plants Res, 2011; 5(16): 3643-3652.

Sadrati N, Daoud H, Zerroug A, Dahamna S, Bouharati S. Screening of antimicrobial and antioxidant secondary metabolites from endophytic fungi isolated from wheat (Triticum durum). J plant prot res, $2013 ; 53(2)$.

Sahu S, Chaturvedi R, Mathew B, Behra P, Divya R, Venketesha RT, Sadanandan B. Antibacterial and antioxidant activity of endophytic bacteria isolated from Annona muricata. Int Rev Appl Biotechnol and Biochem, 2014; 2(1): 179-188.

Saravanan S, Parimelazhagan T. In vitro antioxidant, antimicrobial and anti-diabetic properties of polyphenols of Passiflora ligularis Juss. fruit pulp. Food Sci Hum Wellness, 2014; 3: 56-64.

Schulz B, Wanke U, Draeger S, Aust HJ. Endophytes from herbaceous plants and shrubs: effectiveness of surface sterilization methods. Mycol. Res, 1993; 97 (12): 1447-1450.

Strobel G and Daisy B. Bioprospecting for microbial endophytes and their natural products. Microbiol Mol Biol R, 2003; 491502 .

Vidyalakshmi KS, Vasanthi HR, Rajamanickam GV. Ethnobotany, phytochemistry and pharmacology of Mussaenda species (Rubiaceae). Ethnobot Leaflets, 2008; 12: 469-475.

Yadav M, Yadav A, Yadav JP. In vitro antioxidant activity and total phenolic content of endophytic fungi isolated from Eugenia jambolana Lam. Asian Pac J Trop Med, 2014; 7(1): S256-S261.

Zeng PY, Wu JG, Liao LM, Chen TQ, Wu JZ, Wong KH, In vitro antioxidant activities of endophytic fungi isolated from the liverwort Scapania verrucosa. Genet Mol Res, 2011; 10 (4): 3169-3179.

\section{How to cite this article:}

Gunasekaran S, Sathiavelu M, Arunachalam S. In vitro antioxidant and antibacterial activity of endophytic fungi isolated from Mussaenda luteola. J App Pharm Sci, 2017; 7 (08): 234-238. 